\title{
Centre Right and Radical Right Party Competition in Europe: Strategic Emphasis on Immigration, Anti-Incumbency, and Economic Crisis
}

\begin{abstract}
We examine centre right and radical right party competition. We argue that centre right parties - particularly non-incumbents - recognise economic crises as electoral opportunities for radical right parties and respond with the strategic emphasis of immigration in mass appeals. To test this, we merge party performance data with expert surveys across 24 European Union countries to examine parties' electoral performances during the 2008 economic crisis. We find that non-incumbent centre right parties benefited from emphasising immigration, performing better than radical right parties. Second, incumbent centre right parties that did not emphasise immigration lost out electorally, providing an opportunity for far-right parties to benefit from immigration in this economic context. Qualitative case studies further suggest that while these effects appear to be more pronounced in Western Europe, the results are consistent across the East and West. The findings suggest a reconsideration of immigration as an exclusive issue for far-right electoral success.
\end{abstract}

Keywords: Centre Right Parties; Radical Right Parties; Strategic Emphasis; Economic Crisis; Party Competition; Anti-incumbency Effects

\author{
James F. Downes ${ }^{1}$ \\ The University of Hong Kong \\ European Union Academic Programme Hong Kong \\ jfdownes@hku.hk \\ Matthew Loveless \\ European University Institute \\ Center for Research \& Social Progress (CeRSP) \\ m2loveless@gmail.com
}

Downes, James and Matthew Loveless. 2018. “Centre Right and Radical Right Party Competition in Europe: Strategic Emphasis on Immigration, Anti-Incumbency, and Economic Crisis" Electoral Studies 54: 148-158. DOI: 10.1016/j.electstud.2018.05.008

\footnotetext{
${ }^{1}$ For all correspondence relating to the paper and the online appendix, please contact the first author.
} 


\section{INTRODUCTION}

There has been a great deal of scholarly research on European populist radical right parties following the financial and subsequent economic crisis of 2008 (Arzheimer 2009; Ford and Goodwin 2014; Goodwin and Milazzo, 2015; Kriesi and Pappas, 2015; Hernández and Kriesi 2016). Whilst scholars have examined the stances and strategies of both mainstream centre right parties' and radical right parties (see Tavits and Letki 2014; Halikiopoulou and Vasilopoulou 2013; Pardos-Prado et al, 2014; Pardos-Prado 2015), few have considered the effects of centre right parties' electoral strategies on the electoral fortunes of the radical right party family, particularly in times of economic crisis. ${ }^{2}$

Contemporary centre right parties in Europe are often known for their ideological focus on the free market economy and law and order, alongside their promotion of traditional institutions and values in society (Bale 2008; Heywood 2012; Odmalm and Bale 2015). At the same time, the strategies they use to emphasise the immigration issue are less discussed in the academic literature, as are the issue's electoral implications for this party family in times of economic crisis. There is a paucity of studies that have systematically investigated how radical right and centre right parties compete for similar voters during times of economic crisis, particularly around the immigration issue (although see Bale, 2008; Bale et al, 2013; Mudde, 2014), which we see as a key gap in the current literature (see Pardos-Prado, 2015). Therefore, we seek to investigate party competition by examining how centre right parties might seek to outmanoeuvre radical right parties during times of economic crisis.

We argue that centre right parties recognise economic crises as opportunities for radical right parties to seek to secure more support through appeals over immigration. In response, centre right parties - particularly non-incumbents strategically emphasise the same issue to retain and even attract voters potentially receptive to such mass appeals. To test this, we use

\footnotetext{
${ }^{2}$ The terms 'populist radical right', 'radical right' and 'far-right' are used interchangeably throughout this paper.
} 
the ParlGov dataset of party performance of European national parliamentary elections merged with an expert survey data on European parties (Rohrschneider and Whitefield 2012). We test our theory against competing theories of issue-based voting during the 2008 economic crisis. We explore the implications of our 'strategic emphasis' theoretical framework further with qualitative case studies of right-wing party competition.

While the results correspond to the larger economic voting literature, showing worse electoral performance for incumbent parties through a widespread anti-incumbency effect (see Kriesi and Pappas, 2015; Duch, 2008; Hobolt et al, 2012), we find evidence that centre right parties' strategic emphasis on the issue of immigration appears to mitigate their electoral losses by undermining the far- right's assumed exclusive exploitation of the issue. In addition, radical right parties did not make significant electoral gains from emphasising immigration and nonincumbent centre right parties which did emphasise immigration performed considerably better electorally (than radical right parties). Correspondingly, centre right parties (both incumbents and non-incumbents) which did not emphasise immigration lost out electorally. Given that the immigration issue has traditionally been viewed as an electoral advantage to radical right parties in recent times (see Mudde, 2007; Arzheimer, 2009; Goodwin and Milazzo, 2015), these findings are somewhat surprising and in turn have important implications.

Below we review the theories behind the electoral issue of immigration and right-wing parties. We then develop our theory based on the gap in the literature concerning the electoral strategies of both centre right and radical right parties in the context of economic crisis. Using existing data on parliamentary electoral performance merged with an expert survey of parties and additional macro-level controls, we then test this theory against existing theories in the literature. We conclude with a discussion of what these results mean for the study of contemporary electoral politics. 


\section{THEORY: STRATEGIC EMPHASIS}

We argue that centre right parties see times of economic crisis as opportune moments for radical right parties to seek to increase their electoral advantage predominantly through appeals over immigration. Centre right parties - particularly non-incumbents - strategically emphasise the same issue to retain and/or attract voters potentially receptive to such mass appeals. To develop this framework, we draw together separate strands of existing theory. The first is the notion of strategic timing, namely, economic crises can act as a crucial moment for far-right parties and centre right non-incumbents to seek to improve their electoral chances. This is, strategic emphasis is strategic inasmuch as economic crises heighten voter volatility with voters disaffected with - and eager to punish - incumbents; thus, creating an opportunity for non-incumbents - including both far-right parties and centre right parties - to exploit the economic crisis period for electoral gain. The second strand comprises of centre right parties' credible and observed emphasis of the issue of immigration. The emphasis here refers to the high salience on immigration as part of their mass appeal strategies. We take up both strands below.

While mainstream centre right parties may be encumbered by a variety of factors, such as history and reputation, radical right parties often have the advantage of non-incumbency and often appear as a protest vote; namely, an expression of dissatisfaction with mainstream political parties, anti-political establishment rhetoric, and in Europe opposition towards the European Union (EU) (see Norris, 2005; van der Brug et al, 2000; van der Brug et al, 2005; Werts et al, 2012). In the context of greater voter volatility in Europe (Dalton and Wattenberg 2000), periods of economic crisis will conceivably provoke voters to question the credibility of governing mainstream political parties. Non-incumbents, particularly 'niche' parties such as radical right parties, are in a position to benefit electorally from this context (Meguid, 2005). 
An example of this is the 'economics breeds extremism' theory which posits increased electoral performance for radical right parties during times of economic crisis as a function of their capitalizing on nationalist sentiment (see Mudde, 2014; 2016; Halikiopoulou and Vasilopoulou 2014). Specifically, radical right parties may try to exploit economic insecurity in the form of scapegoating, in which ethnic in-groups may scapegoat ethnic out-groups, such as immigrants, to channel economic frustrations (see Arzheimer 2009; Ford and Goodwin 2010; Halikiopoulou and Vasilopoulou 2013; Goodwin, 2014; Mudde 2014; Goodwin, 2015).

However, the empirical literature on radical right performance voting and macroeconomic conditions does not offer a conclusive answer to this question (see Mudde, 2014; 2016). Though the evidence does suggest that radical right performance during declining national economic conditions is a good opportunity for pursing electoral advantages, macroeconomic trends have been shown to play a weak role in explaining increased levels of support for the radical right (Knigge, 1998; Lubbers et al, 2002; Kessler et al, 2005; Werts, 2010; Cochrane et al, 2012; Werts et al, 2013; Halikiopoulou and Vasilopoulou 2014). Other scholars show that declining macroeconomic conditions can produce increased support for the radical right at the country level (Baimbridge et al, 1994; Baimbridge et al, 1995; Jackman and Volpert, 1996; Arzheimer at al 2003; Golder, 2003; Arzheimer et al, 2006; Arzheimer, 2009; Stockemer 2016), a result reflected at the regional level as well (Stockemer, 2016; Lubbers et al, 2001). Other scholars suggest that macroeconomic conditions can be important in partly explaining the rise in far-right party success (Norris, 2004; Pardos-Prado, 2015; Halikiopoulou et al, 2015). ${ }^{3}$ While the evidence above has not yet reached the level of a widely shared or accepted account, it is conceivable that declining macroeconomic performance (antiincumbency effects) can provide electoral opportunities for far-right parties to increase their

\footnotetext{
${ }^{3}$ This does not exclude the racial right - in specific cases - improving their performances during periods of economic growth.
} 
electoral performance. Consistent with this, our theory does not argue that the onset of the economic crisis increases the electoral performance of the radical right, but simply that this period offers electoral opportunities for them, primarily due to greater voter volatility and antiincumbency effects.

In other words, centre right parties have the experience to not only recognise the economic crisis as a time of greater voter volatility and increased anti-incumbent sentiment but also the electoral threat that 'niche' parties such as the far-right poses at this time, particularly around this issue (Bale, 2008; Bélanger et al, 2008). In addition, other scholars (Meguid, 2005) have drawn on issue salience models in demonstrating that mainstream parties can influence the electoral fortunes of 'niche' parties on certain specific issues that have important implications for party competition. Our theory of 'strategic emphasis' builds on this in further testing these effects in regard to mainstream centre right parties and the context of economic crisis.

Why do centre-right parties then choose to emphasise the issue of immigration? For one reason, as an electoral issue, immigration has been shown to be both central - and crucial - to voters' support for radical right parties (Jackman and Volpert, 1996; Arzheimer at al 2003; Golder, 2003; Arzheimer et al, 2006; Arzheimer, 2009; Lucassen et al, 2011; Lubbers et al, 2002). Specifically, in Western Europe, increased electoral support for radical right parties has been associated with anti-immigrant sentiment and nationalism (Arzheimer, 2009; Mudde, 2014). It is therefore intuitive to expect radical right parties to exploit this central issue at such opportune moments.

Centre right parties can and have offered credible challenges on the issue of immigration. Centre right parties are able to adopt dynamic stances on immigration as they are closer spatially to radical right parties on immigration positions (see Pardos-Prado, 2015; Van Spanje, 2010). For example, in the United Kingdom, the Netherlands and France, centre right parties have been 'closer' to radical right spaces and have also made the issue salient in their party 
manifestos (see Bale et al, 2010; Pardos-Prado, 2015). Furthermore, there have also been examples of centre right and radical right parties entering into coalition, particularly with the 1999-2002 coalition between the far-right Freedom Party of Austria (FPÖ) and the centre right Austrian People's Party (ÖVP). At the same time, there are also examples recently in Western Europe, of centre right parties, such as the People's Party for Freedom and Democracy (VVD) in the Netherlands and the New Flemish Alliance (N-VA) in Belgium realizing the electoral potential that the immigration issue can provide (van Heerden et al, 2013).

Unlike far-right parties, centre right parties may need to contend with potentially competing stances on immigration. Generically, immigration is directly linked to key right-wing issues such as keeping taxation low, maintaining law and order, alongside national security that is likely to appeal to a core base of the centre right electorate (see Bale, 2008; Bale et al, 2010; Van Spanje, 2010; Pardos-Prado, 2015). Furthermore, centre right parties have tended to place emphasis on cultural traditions, social stability and national identity - all of which make an emphasis on immigration natural for the centre right to weave into its overall ideological argument.

There are, however, two potentially competing factions within mainstream right parties. Centre parties can adopt more hard-line immigration stances that can lead to electoral rewards by capturing voters from radical right parties (Odmalm and Bale 2015). This can produce internal party splits on ideology, "[creating] a tension between market liberal and culturally conservative wings" (ibid., p. 5). Namely, the market liberal wings are likely to prefer a more moderate and supportive stance towards immigration (i.e.: merging with labour fluidity) whereas the cultural conservative wing is likely to advocate a more hard-line stance, seeking to place restrictions on the number of immigrants that can enter the country. ${ }^{4}$

\footnotetext{
${ }^{4}$ Whether centre right parties offer a moderated version of anti-immigration or a softer, market-centered version (i.e.: an unspoken amenability to immigration) is not relevant in our theory. In any case, we control for centre right parties' positions on immigration by including a measure of party positions (pro- v. anti- immigration) on immigration.
} 
We argue that centre right parties are rooted in pragmatism and are ultimately 'officeseeking' parties. As such (see Heywood, 2012), centre right parties are likely to realise that the more important distinction in this economic context is their electoral status (i.e.: 'incumbent' and 'challenger') and thus increased anti-immigration messaging alongside other appeals to voters disaffected with incumbent parties. That is, in addition to ownership over 'managing the economy', centre right parties can bring immigration into their platforms as part of a larger and more moderate ideological offering versus (an extreme) centrepiece. This argument corresponds to empirical work that shows centre right parties are often viewed by voters as a party that can best deliver on the immigration issue (see Iversflaten, 2005; Bale, 2008; Bale et al, 2013).

In doing so, centre right parties - particularly non-incumbents - can offer a timely and strategic emphasis to undermine the potential electoral effectiveness of the issue of immigration for the radical right during the crisis period (see Meguid, 2005). As stated above, we make the assumption in our theoretical model that economic crises are merely an opportune moment for radical right parties to increase their specific mass appeals on immigration in the hope of attracting potentially de-aligned supporters away from mainstream parties. Such periods not only provoke voters to hold incumbent parties to account for the overall state of the economy (Kriesi and Pappas, 2015), but also provide the opportunity for non-incumbent parties to offer strong non-establishment party appeals. Thus, centre right parties strategically emphasise the issue of immigration in an attempt to mitigate the possible electoral boost antimainstream appeals might provide radical right parties.

\section{HYPOTHESES}

The strategic emphasis theoretical framework produces three core hypotheses $(\mathrm{H} 1-\mathrm{H} 3)$. We first examine patterns of electoral volatility and protest voting, in the context of economic crisis, with voters less aligned to parties, and thus more prone to punish poorly performing 
incumbents (Kriesi and Pappas, 2015). Anti-incumbency creates an opportunity for insurgent radical right parties to benefit electorally, at the expense of mainstream parties (H1).

H1: In line with theories of protest voting (incumbency-punishment), incumbent mainstream centre right parties will lose out electorally in the crisis period.

Building on the central theory, mainstream centre right parties that respond to the economic crisis by emphasising the immigration issue as a strategy to attract and retain voters $(\mathrm{H} 2)$ will perform electorally better.

H2: Centre Right Parties that emphasise immigration will perform better electorally than radical right parties.

However, in line with the theoretical framework, if centre right parties 'downplay' or 'remain silent' on immigration, then this allows the far-right to gain coverage of the issue amongst voters and conceivably profit electorally from the centre right's absence on this issue domain (H3). We note that an important implication of (H3) is that radical right parties will benefit electorally in the centre right's failure to perform well. This is taken up in the case study analysis section in the latter part of the paper.

H3: Centre Right Parties that do not emphasise immigration will perform electorally worse. 


\section{RESEARCH DESIGN}

\section{Data}

Our research question requires an party-level approach and merges two datasets together. First, we use the ParlGov dataset (Döring and Manow 2015) which contains data on parties' electoral performances in national parliamentary elections across Europe, including the percentage of votes each party in each country won during parliamentary elections that are key to our analysis. The central dependent variable is the change in electoral performance measured as the difference in percentage of aggregate votes between the national parliamentary election before the 2008 crisis to the first election after the crisis. In the case of an election during 2008, these elections are used as the base, so as each country's parliamentary election includes the onset of the economic crisis in 2008. As a measure of electoral performance, a positive score means that a political party performed better electorally (i.e.: increased their vote share) from the previous election and a negative score means it performed electorally worse.

These party performance data are then merged with expert surveys that include Western and Central-Eastern Europe and have been commonly used in the party competition literature (Rohrschneider and Whitefield, 2012). This dataset includes experts' assessments of parties' issue positions and salience (emphasis) on a number of key European electoral issues $(N=209$ experts). For parties to be included in the survey, two core criteria were used. Firstly, parties had to have achieved representation (seats) in the national parliament and secondly had to have received at least $2 \%$ of the national vote in the last parliamentary election. ${ }^{5}$ These expert data have a high degree of reliability and consistency in terms of the empirical measures, matching, for example, the Comparative Manifesto Research Project and the Chapel Hill Expert survey

\footnotetext{
${ }^{5}$ This paper is unable to include the following radical right parties: The British National Party (BNP), the United Kingdom Independence Party (UKIP), Golden Dawn (Greece) in the empirical analysis as the Rohrschneider-Whitefield expert survey did not include these three parties. The Hungarian Justice and Life Party (MIEP) did not meet the $2 \%$ voting threshold criteria as outlined in the Rohrschneider-Whitefield expert survey. In addition, Jobbik was also not included as they were not included in the Rohrschneider-Whitefield expert survey.
} 
(see Dalton et al., 2011; Rohrschneider and Whitefield, 2012; Whitefield et al. 2006). The Rohrschneider-Whitefield expert survey has two advantages for our analysis: one it covers more issues than other expert surveys such as the CHES and two, it specifically covers the years of the economic crisis (2007-8) that is the central contextual focus of our study.

To define centre right and far-right parties, we used two strategies. Firstly, the Rohrschneider-Whitefield expert survey placed political parties along the left-right ideological dimension. As a starting point, we produced country-specific means for each country that where then standardised (set to zero) with a standard deviation of one for each country. Thus, the 'right' was defined as any party with a score of more than zero (to the 'right' of the mean). 'Radical' parties fell outside of the first standard deviation. Secondly, we matched our classification with both the 2010 Chapel Hill Expert survey (see Bakker et al, 2015) and Mudde's recent classifications $(2013 ; 2014)$ of far-right parties. This approach provides increased reliability, accuracy, and consistency of the party classifications used here (see Table 1). Additionally, some empirical research has disregarded smaller competitors to maintain focus on the mainstream right and mainstream left (see Meguid 2005). This paper adopts the empirical strategy of including all parties to maintain the number of observations, thus allowing for a deeper analysis and for the observed rise in radical right parties in Europe (see Hernández and Kriesi 2016). Finally, we remind readers that this classification process refers to 2008. For example, whilst the Hungarian party Fidesz has recently transformed ideologically into more of a radical right party, here it is classified as a centre right party consistent with both its positions in 2008 and the expert party classification data used here. The final sample size is comprised of 208 political parties across 24 countries in Western and Central-Eastern Europe. The full breakdown of party classifications and measurement can be found in Appendix A. 
We acknowledge that there are potentially salient variations between Western and CentralEastern Europe in regard to political parties, party competition dynamics and the underlying political system, we draw on both contexts primarily in order to enhance the sample size (generalisability) of this paper. Including both the West and East contexts also allow us to examine important variations on key issues such as immigration that are likely to structure competition between right-wing parties in the crisis period.

Therefore, the countries included in this paper are: Austria, Belgium, Bulgaria, the Czech Republic, Denmark, Estonia, Finland, France, Germany, Greece, Hungary, Ireland, Italy, Latvia, Lithuania, Poland, Portugal, Romania, Slovakia, Slovenia, Spain, Sweden, the Netherlands and the United Kingdom. ${ }^{6}$

\section{Independent Variables}

The main independent variables include party-level variables. The central independent variable is the salience of immigration. Issue salience is measured on a 1-7 scale with higher values meaning that the issue featured prominently as part of mass appeals and lower values meaning that it was not a meaningful part of electoral appeals. We also controlled for key issue salience indicators such as welfare and the market economy $(1=$ Not Important, $7=$ Very Important to mass appeals). The mean and standard deviation of the salience of immigration for far right parties is $(5.99,1,15$ : range: $3.6-7)$ and for centre-right parties $(4.39,0.85$ : range: 2.7-6.6).

Previous party competition literature has shown that radical right parties have tended to perform electorally better when holding neo-liberal economic policies (see Kitschelt, 1995). However, recent research (see de Lange, 2007; Carter, 2005; Arzheimer, 2009; Rovny, 2013) has argued against this claim, providing empirical evidence to show that radical right parties

\footnotetext{
${ }^{6}$ Moldova, Ukraine and Russia are not examined in this paper as the political contexts are vastly different politically to make any meaningful comparisons. As a result, these three countries were omitted from the final dataset. Additional EU countries (Cyprus, Croatia, Luxembourg and Malta) are not included as they did not feature in the original Rohrschneider-Whitefield expert survey,
} 
tend to perform better electorally when they present a more centrist economic position (i.e. state and government intervention in the economy). Ideologically, centre right parties are traditionally known for cutting taxation and emphasising free market economics (see Girvin, 2005; Heywood, 2012). In line with this theoretical distinction, different variables are used to model socio-economic stances and emphasis for both sets of parties.

In order to test the role played by spatial/proximity factors, a number of issue positions are examined. In line with the radical right voting literature (see Pardos-Prado, 2015; Arzheimer, 2009; Mudde, 2007); socio-cultural issue positions including a variable measuring antiimmigrant positions (1= Pro- Immigration, 7= Anti- Immigration); support for the market economy $(1=$ Against Markets, $7=$ Pro Market $)$; an active state role in providing welfare $(1=$ Universal, $7=$ Means-tested $)$; and anti-EU positions ( $1=$ Support, $7=$ Oppose $)$.

Part of our theory includes the role of macroeconomic crisis. While devastating in the aggregate, the 2007-8 financial turned economic crisis did not affect all European countries equally. To account for the cross-national variation in the severity of the economic crisis, we include the change in GDP annual growth; the change in unemployment (both form the World Bank); and change in income inequality (Solt 2014) measured between 2008 and 2012 as macroeconomic controls for the varied national impact of the economic crisis.

We also attempted to include the change in migration levels (2008-2012). While the most complete set of data come from the Organization for Economic Co-operation and Development (OECD), these data are incomplete. Given our small sample size, particularly for far-right parties, official migration numbers could not be included, reducing the overall sample size considerably. Their inclusion in the analysis produced largely similar results but given the substantial loss of observations, this was dropped from the final empirical models. ${ }^{7}$

\footnotetext{
${ }^{7}$ Theoretically, this is not problematic as we argue for the salience of immigration and make no assertion about actual levels.
} 
Finally, institutional variables are included in line with the existing literature. Plurality electoral systems tend to limit electoral support for the far-right; whereas proportional representation electoral systems tend to facilitate support for radical right parties (see Norris, 2005; Carter, 2005; Arzheimer and Carter, 2006). We use the Gallagher Index of the change in disproportionality levels (2008-2012). ${ }^{8}$ We also include a dummy variable for incumbency (1) or not (0). While the literature is somewhat unclear on the importance of the East/West variation, we include a dummy variable for post-communist countries (1) or not (0).

\section{ANALYSIS}

In Table 2, we provide direct tests of $\mathrm{H} 1$ (incumbency) and $\mathrm{H} 2$ (salience of immigration) for both centre right (Model 1) and far-right parties (Models 2-3). With a dependent variable of the change in electoral performance measured as the difference in percentage of aggregate votes between the national parliamentary election, we use OLS regression models with robust standard errors. ${ }^{9}$ Each model includes both variables derived from our theory as well as those control variables derived from the literature. In doing so, we can investigate the extent to which centre right incumbents lost out electorally in the crisis period and at the same time, the degree to which centre right parties benefited from emphasising the immigration issue in the economic crisis period.

\section{$<<T A B L E 2$ ABOUT HERE >}

Model 1 shows a strong and statistically significant anti-incumbency effect for centre right parties. This result is in line with empirical evidence found by a number of contributions in the literature (see Lewis-Beck, 1986; Alvarez et al., 2000; Duch, 2008; Hobolt et al., 2012; Kriesi and Pappas, 2015). Most significantly, empirical evidence is found for $\left(\mathrm{H}_{2}\right)$ with centre right

\footnotetext{
${ }^{8}$ Strictly speaking, this variable covers the change in disproportionality for the last two national elections in the 2008-2012 electoral period.

${ }^{9}$ Hierarchical linear regression models were not produced for two main reasons. Firstly, the sample size of 24 EU countries is too small and renders multilevel modelling potentially problematic. Secondly, there are only 19 far-right parties that feature in this economic context and multilevel models would not be able to converge with such a small sample size, thus limiting and calling the external validity of this study into question.
} 
parties in Europe that emphasised (issue salience model) the immigration issue performing electorally better during the crisis period and increasing their vote share considerably (see Pardos-Prado, 2015; Odmalm et al, 2015).

Two notable cases illustrate this trend and show that non-incumbent centre right parties benefited electorally from an emphasis on immigration. Firstly, the non-incumbent New Flemish Alliance Party (N-VA) Party in Belgium arguably outperformed the radical right Flemish Interest (VB) Party in Belgium through an emphasis on immigration during this electoral period. Secondly, the non-incumbent centre right party, the People's Party for Freedom and Democracy (VVD) in the Netherlands also appeared to prosper electorally from emphasising the immigration issue in their party strategies. In contrast to the centrality of the issue salience model on immigration, Model 1 shows that adopting hard-line stances (issue position model) on immigration was not a vote winning strategy.

Model 2 in Table 2 examines how radical right parties performed on a number of issue positions and issue salience, alongside controlling for party and country-level variables in the economic crisis period. The incumbency variable is not included for the radical right party model as there is only one case (the SNS Party in Slovakia). Model 2 shows that radical right parties that emphasised immigration did not perform better electorally. In addition, the postcommunist dummy is not significant. ${ }^{10}$ This finding casts some doubt on whether radical right parties can exclusively benefit electorally from emphasising immigration in the crisis period.

$$
<<\text { FIGURE } 1 \text { ABOUT HERE >> }
$$

A multiple regression coefficient plot with $95 \%$ confidence intervals is also included to provide a means to visualise the magnitude of the electoral effect for centre right and radical

\footnotetext{
${ }^{10}$ For far-right parties, there are statistically significant differences in both salience $(\mathrm{t}=5.63, \mathrm{df}=18, \mathrm{p}<0.001)$ and position $(\mathrm{t}=2.89, \mathrm{df}=18, \mathrm{p}<0.01)$ of immigration between East and West, in which immigration is both less salient and more pro-immigrant in Eastern Europe. Therefore, we also interacted the post-communism dummy with both salience and positon of immigration and the results are the same. The results are available from the authors on request.
} 
right parties when emphasising immigration (see Figure 1). This shows the impact of the salience of immigration whilst including the main independent and control variables from Models 1 and 2 in Table 1 . Figure 1 shows that centre right parties appeared to be the main beneficiaries of emphasising immigration (issue salience). In contrast, radical right parties did not benefit from emphasising the immigration issue during the crisis period. ${ }^{11}$

Model 3 in Table 2 includes an additional radical right party model. As there are only 19 radical right parties in Model 2 and due to the limited sample size, the Model in Table 3 seeks a more parsimonious approach in modelling fewer independent variables, namely the most important variables that have been proven in past research to drive support for this party family (see Arzheimer, 2009; Mudde, 2007; Werts et al, 2012). It continues to show that radical right parties did not benefit substantially from emphasising and talking up the immigration issue (issue salience). All three models were tested for multicollinearity and are within the accepted limit. $^{12}$

We want to emphasise that the small sample size of the far-right party model is to be treated with caution, especially in regard to making definitive inferences about the immigration issue. Specifically, conclusions about null findings based on such a sample - and in particular, the constraint of limited variance - should seek corroborating evidence. As such, to provide increased robustness to the above analysis, we provide two strategies. Firstly, we estimated the far-right model and dropped each party one by one to see if the model was not sensitive to a single party. The results did not lead us to suspect the results were overly driven by any one party. Secondly and most importantly, we supplement the main quantitative analysis above through a case study approach. This allows us to highlight key patterns and trends implied by our theory and the results above by specifically providing different situations of competition

\footnotetext{
${ }^{11}$ For these models, in the occasional case of multicollinearity (high VIF), we have made every effort to include the most theoretically relevant combination of variables.

$12 \mathrm{We}$ also ran an additional robustness check on our data. For example, an identical model was run for centre left parties and showed that centre left parties did not benefit from emphasising the immigration issue.
} 
derived from our 'strategic emphasis' theoretical framework. In addition, while the empirical analysis above shows clear patterns for the electoral success of centre right parties' strategic emphasis, particularly 'challenger' parties (non-incumbents), we are unable to directly test $\left(\mathrm{H}_{3}\right)$. We identify and investigate key party competition patterns between the centre right and radical right in the context of party competition on the immigration issue between both centre right and far-right parties in the economic crisis period.

\section{Case Study Approach}

\section{The 'Type' of Centre Right Party Matters}

The empirical evidence thus far has demonstrated that centre right parties appear to perform better electorally when emphasising the immigration issue. Radical right parties did not perform particularly well on the issue in times of economic crisis. A closer inspection of the dataset reveals that a number of centre right parties performed well electorally when emphasising the immigration issue. Notable examples include a number of non-incumbent centre right parties, such as the New Flemish Alliance Party (N-VA) in Belgium, the People's Party for Freedom and Democracy (VVD) in the Netherlands, alongside the Swedish Moderate Party (M), the UK Conservative Party (CON), the Liberal Alliance in Denmark (NA) and to a lesser extent the Liberal Party (VENSTRE).

However, a number of centre right parties, particularly incumbents performed poorly. Notable examples include incumbent centre right parties that saw their vote share decrease in national parliamentary elections across the economic crisis period. These cases include the Centre Party (KESK) coalition government with the National Coalition Party (KOK) in Finland and Angela Merkel's Christian Democratic Union Party (CDU) in Germany.

Furthermore, whilst incumbent centre right parties such as the UMP in France and the Austrian People's Party (ÖVP) emphasised immigration, they performed electorally worse. This pattern also suggests that even when emphasising immigration, specific incumbent centre 
right parties still lost out electorally in the economic crisis. These findings point to a wider antiincumbency effect. The main patterns demonstrated here appear to provide evidence for $\left(\mathrm{H}_{1}\right)$ in showing that incumbency alongside a lack of emphasis on immigration is likely to have hindered the electoral success of these centre right parties in the crisis context, providing more impetus for the far-right to claim the immigration issue in these countries.

\section{Radical Right Parties}

Upon closer inspection of the dataset, there are a number of radical right parties that benefited electorally from an emphasis on immigration during the crisis context. Most notably, the Finns Party (PS) in Finland, Geert Wilders' Party for Freedom (PVV) and the French Front National (FN). The results in Austria show that both far-right parties, the Austrian Freedom Party (FPÖ) and Alliance for the Future of Austria (BZÖ) Party increased their overall vote share in national parliamentary elections, at the expense of the incumbent centre right ÖVP.

However, these findings also suggest that a number of radical right parties lost out electorally when emphasising immigration. The Flemish Interest Party (VB) in Belgium and the Danish People's Party (DF) are two such examples saw their respective vote shares decline over the electoral period. Evidently, placing emphasis on the immigration issue in these countries did not translate into concrete electoral gains for these radical right parties and centre right parties also arguably played an important role in this process.

\section{Patterns of Party Competition: Economic Crisis Context}

Drawing on our empirical findings, we outline some key patterns. Tables 3 and 4 below depict the key cases in more detail. These tables outline the percentage change in vote shares for both centre right and radical right parties in key cases, alongside the emphasis placed on immigration by both party families. In terms of defining 'low' salience and 'high salience' on the immigration issue, this paper makes two distinctions. Political parties that scored $1-4$ on 
this measure did not particularly emphasise immigration, whereas parties that scored 5-7 on this issue emphasised the issue considerably in their party strategies.

\section{< <TABLE 3 ABOUT HERE >}

Key cases from the Western European context are outlined in this section and show how the 'type' (incumbent v. non-incumbent) of centre right party matters, in being able to emphasise the immigration issue (talk the issue up) and prosper electorally during the crisis context.

The cases of the Netherlands and Belgium show that (1) incumbent centre right parties (antiincumbency effect) performed worse electorally and at the same time did not particularly (2) emphasise the immigration issue, thus leaving space open for (3) non-incumbent centre right parties to exploit through talking up the immigration issue. Figure 2 further shows the extent to which emphasising immigration can influence the electoral fortunes of specific centre right ('incumbents' and 'non-incumbents') alongside radical right parties in this electoral context, particularly in complex multi-partyist political systems such as in the Netherlands and Belgium (Flanders). ${ }^{13}$

\section{$<<$ FIGURE 2 ABOUT HERE >>}

A key finding is the Belgian case, which highlights how the centre right N-VA (+8\%) outperformed the radical right party VB (-4\%) when emphasising immigration. In the Netherlands, incumbent centre right parties performed worse electorally, with the Christian Democrats (CDA) witnessing a sharp decrease (-13\%) alongside their centre right coalition partners Christian Union (CU) (-1\%). At the same time, the centre right 'challenger' VVD Party $(+6 \%)$ increased their vote share alongside the far-right PVV $(+10 \%)$. The Danish results

\footnotetext{
${ }^{13}$ Appendix C provides a comprehensive breakdown (vote shares, seat shares, incumbency status and emphasis on immigration) of the four key cases (Netherlands, Belgium, France and Finland) that illustrate the 'strategic emphasis' theory alongside the general electoral picture in each country. Party competition in Belgium is highly complex due to the consociational political system and nature of the constitution. Party competition in the region of Flanders (Dutch speaking) is investigated instead of Wallonia (French speaking) primarily as rightwing competition is considerably stronger in Flanders.
} 
provide an additional case where centre right parties (VENSTRE and NA) performed electorally better than the radical right (DF).

\section{< TABLE 4 ABOUT HERE >}

An additional pattern demonstrated that in specific countries, radical right parties outperformed centre right parties on the immigration issue (Finland, France and Austria) largely due to two dual mechanisms taking place; (i) a wider anti-incumbency effect and by the centre right incumbents (ii) not particularly emphasising immigration.

Finland is a notable case of both mechanisms, with the far-right PS Party increasing its vote share $(+15 \%)$ considerably, with the incumbents KESK $(-7 \%)$ and KOK $(-2 \%)$ suffering electorally in this economic context and not emphasising the importance of the immigration issue. The findings for France and Austria show that even though centre right parties emphasised immigration (UMP and ÖVP), being an incumbent was electorally damaging in this economic context. Though these findings are preliminary, these results build on the limitations of the OLS regression models as they highlight differing patterns of party competition on immigration, predominantly in Western Europe between both party families in the context of economic bad times (anti-incumbency effects). Figure 3 further shows important West-East differences in party competition between centre right parties, particularly in regard to the more pronounced effects in Western Europe. Three key patterns can be observed from Figure 3. Firstly, centre right 'challenger' parties that emphasised immigration tended to perform electorally better in Western Europe (VVD in the Netherlands and N-VA in Belgium). Secondly in Western Europe, centre right 'incumbent' parties that emphasised immigration tended also to perform electorally worse (UMP and ÖVP) and again highlights important antiincumbency effects. Thirdly, the immigration issue tended to be less important amongst 'incumbent' and 'challenger' centre right parties in Central-Eastern Europe. It is also not clear 
whether different 'types' of centre right parties benefited from emphasising immigration in Central-Eastern Europe.

< <FIGURE 3 ABOUT HERE>> 


\section{DISCUSSION}

We have argued that centre right parties can compete with far-right parties with the timely and strategic emphasis on the immigration issue in party platforms. The findings here suggest that there may be three distinct patterns underlining party competition between radical right and centre right parties in the context of the recent economic crisis. Firstly, the empirical analysis demonstrated that specific 'types' ('non-incumbents) of centre right parties appeared to perform better electorally than radical right parties. Contextually, the period of economic crisis is an opportune moment for voters to express their displeasure and seek alternatives. Centre right parties appear to have been strategically aware of this greater voter volatility and potential for insurgent and anti-incumbents such as the radical right to make electoral headway.

A second and more complex pattern of party competition also emerged in this economic context. Both centre right and far-right parties emphasised the immigration issue and prospered electorally in national parliamentary elections across the crisis period (particularly in the Netherlands). The Western European context showed the strongest evidence for this pattern. Crucially, these cases demonstrated that party competition on the immigration issue acted as a central dimension of political contestation in these countries. Holding anti-immigrant positions also decreased the electoral vote share for radical right parties during the economic crisis (see also Carter, 2005; Odmalm and Bale, 2015).

The third general pattern appears to be the (still) powerful role of anti-incumbency in the context of economic crisis. Even when emphasising immigration, incumbent centre right parties tended to be punished by voters and lose out electorally in national parliamentary elections. Notable cases include Finland, France and Austria where the radical right performed better electorally than the centre right when emphasising the immigration issue. As mentioned previously, our theory is concerned with the use of immigration as a mass appeal strategy and 
we make no inferences as to the actual level of immigration and its effects on party competition (see Bale, 2008; Pardos-Prado, 2015; Odmalm and Bale, 2015).

We point out that this analysis focused on centre right and radical right party competition, excluding centre left parties. We have adopted this approach as centre right parties are spatially closer to radical right parties on immigration positions than centre left parties (see PardosPrado, 2015; Van Spanje, 2010). Centre left parties which have engaged the immigration issue have generally seen mixed electoral fortunes. Additionally, centre left parties are also constrained on the immigration issue, due to their more socially liberal and cosmopolitan values alongside the importance that they do not alienate immigrant and ethnic minority electorates which constitute a large and growing source of support for this party family (Bale et al, 2010; Ford and Goodwin, 2014; Marquand, 2015; Van Heerden et al, 2013).

Despite our efforts to provide consistent results, there are a number of limitations to this analysis. Above all, despite using 24 countries across the EU, the radical right model sample size is small $(\mathrm{N}=19)$. While the findings are consistent across alternative specifications, robustness tests, and cases studies, we acknowledge that the data may limit generalisability. It is also limited to a single - albeit significant - economic crisis context. Although we tried to control for the variable cross-national impact of the initial economic crisis with a set of dynamic macroeconomic measures, the full extent and any nationally specific effects may have escaped detection. There are, in addition to the existing literature, a number of national-level features that may potentially shape the nature of this relationship; for example, the centre-periphery cleavage in Spain, the North-South division in Italy, or the role of cultural memory in Germany. We do not intend to minimise the potential importance of these explanations for specific countries. However, our analysis seeks to generate a more general explanation for right-wing party competition. 
As we alluded to earlier, there is one further issue that has received limited attention in the literature; namely, the potential variation of radical right parties across Western and CentralEastern Europe (CEE). We acknowledge that possible East-West differences remain, for example, in terms of party systems and political traditions. For example, Tavits and Letki (2014) have shown that parties of the right in CEE respond to rising inequality by emphasising the issue of nationalism to attract - or distract - potential left voters, specifically parties' "polarization on interests" and "polarization on values" (including nationalism, regionalism, morality, religiosity, treatment of minorities). While there are some similarities to what we have observed here, this aligns more closely with other research that suggests the economic crisis in CEE was more a political than an economic crisis (see Hernández and Kriesi 2016). However, as of 2008 (the time of these data), all of the "post-communist" countries examined here were full members of the EU and our analysis is congruent with the comparative literature by controlling for potential regional differences (see Arzheimer, 2009; Lubbers, et al, 2002). We also acknowledge that the post-communist dummy variable approach used here fails to render the exact nature of any potential cross-regional historical or institutional differences. However, potential variation could be articulated in a number of ways that we cannot take up here for reasons of space (and degrees of freedom) and we thus leave this for future work. Like other scholars before us, we see using the complete set of EU countries as a more substantive and convincing test of the theory.

\section{CONCLUSION}

The political scientist Herbert Kitschelt (1995) coined the phrase 'electoral winning formula' to describe the dominance that specific radical right achieved in the 1990s by adopting neo-liberal economic positions alongside hardline positions on issues such as crime, law and order and immigration. Since Kitschelt's landmark study, a number of scholars have shown how the immigration issue has come to dominate the ideology of the radical right and the 
attitudes of the voters that this party family attracts (see Lubbers et al., 2002; Mudde, 2007; Arzheimer, 2009; Werts et al., 2012). We argue that with the rise of radical right parties in Europe during the 2000s, specific centre right parties spotted an opportunity to win back votes by pivoting towards immigration and talking the issue up ('strategic emphasis'). In this paper we provide preliminary evidence, whereby centre right parties, particularly challengers, can profit electorally when they emphasise immigration in times of economic crisis and, in some cases, outperform the radical right. However, there remain situations in which the centre right performs electorally worse, namely when (1) they are incumbents or (2) they do not emphasise the immigration issue. This suggests that there are electoral opportunities to emphasising immigration in economic bad times, with potential electoral gains for radical right parties. These findings have broad implications for the contemporary party competition literature.

In the context of the recent rise in the number and success of far-right parties in Europe (ongoing migration crisis), competition between the centre right and the far-right continues to be a fertile area for future research. While there may be a theoretical argument for the ideological affinity between centre right and radical right parties, there are few instances of electoral collaboration and formation of governments composed of them. That is, while there is often some overlap in the broad platforms of centre and far-right parties, their inability to overcome existing problems between these two party families ultimately limit their potential collaboration thus setting the stage for electoral competition. Our investigation here is aimed directly at this relationship.

Future party competition research should seek to build on these findings in understanding the electoral fortunes of the centre right across Europe in different economic contexts. This might include investigating how centre right and radical right parties emphasised the issue of immigration outside periods of economic crisis, specifically in the earlier part of the 21 st century; and how this affected both parties' varying electoral fortunes. In order to further 
investigate electoral variations for centre right parties, future research should also seek to disaggregate this party grouping and examine the electoral fortunes of conservative, Christian democratic and market liberal parties interchangeably, particularly in their use of the immigration issue. More work is also needed on the direct contest of both party families over specific and strategic issues such as EU integration (see Spoon et al. 2014; Mair and Mudde 1998). 


\section{BIBLIOGRAPHY}

Alvarez, R Michael, Jonathan Nagler, and Jennifer R. Willette. (2000). "Measuring the Relative Impact of Issues and the Economy in Democratic Elections.' Electoral Studies 19: 237-53.

Arzheimer, Kai, (2009). "Contextual Factors and the Extreme Right Vote in Western Europe: 1980-2002.” American Journal of Political Science, 53.2: 259-275.

Baimbridge, M., Burkitt, B. \& Macey, M. (1994). The Maastricht Treaty: Exacerbating racism in Europe? Ethnic and Racial Studies 17(3): 420-41.

Baimbridge, M., Burkitt, B. \& Macey, M. (1995). The European Parliamentary election of 1994 and racism in Europe. Ethnic and Racial Studies 18(1): 128-30.

Bale, Tim (2008). "Turning Round the Telescope. Centre-Right Parties and Immigration and Integration Policy in Europe." Journal of European Public Policy 15: 315-330.

Bale, T., Green-Pedersen, C., Krouwel, A., Luther, K. R., \& Sitter, N. (2010). "If you can't beat them, join them? Explaining social democratic responses to the challenge from the populist radical right in Western Europe." Political Studies, 58(3): 410-426.

Bale, Tim, Dan Hough, and Stijn van Kessel (2013). "In or Out of Proportion? Labour and Social Democratic Parties Responses to the Radical Right." In Class Politics and the Radical Right, ed. Jens Rydgren. London: Routledge: 110-125.

Bélanger, Éric and Meguid, B.M. (2008). "Issue salience, issue ownership and issue-based vote choice." Electoral Studies 27(3): 477-491.

Bermeo, Nancy and Larry Bartels (eds.) (2014). Mass Politics in Tough Times: Opinions, Votes and Protest in the Great Recession. Oxford: Oxford University Press.

Bustikova, L., and Kitschelt, H. (2009). "The radical right in post-communist Europe. Comparative perspectives on legacies and party competition." Communist and PostCommunist Studies, 42(4): 459-483.

Carter, Elisabeth L. (2005). The Extreme Right in Western Europe: Success or failure? Manchester: Manchester University Press

Dalton, Russell J. and Martin P. Wattenberg. (2000). Parties without Partisans: Political Change in Advanced Industrial Democracies. Oxford University Press.

Dalton, Russell J. and Christopher Anderson. (2011). Citizens, Context and Choice: How Context Shapes Citizens' Electoral Choices. Oxford: Oxford University Press.

De Lange, S. (2007), "A new winning formula? The programmatic appeal of the radical right", Party Politics 13(4): 411-435.

Döring, Holger and Philip Manow. (2015). Parliaments and governments database (ParlGov): Information on parties, elections and cabinets in modern democracies. Source: http://www.parlgov.org/.

Duch, R.M. and Stevenson, R.T. (2008). The Economic Vote: How Political and Economic Institutions Condition Election Results. New York: Cambridge University Press.

Ellinas, Antonis, A. (2013). "The rise of the Golden Dawn: The new face of the far right in Greece," South European Society and Politics, 18:4.

Ford, Robert and Goodwin, Matthew, J. (2010). "Angry white men: individual and contextual predictors of support for the British National Party (BNP)." Political Studies, 58 (1).

Ford, Robert and Matthew, J. Goodwin (2014). Revolt on the Right: Explaining support for the Radical Right in Britain, Routledge.

Golder, M. (2003). Explaining variation in the success of extreme right parties in Western Europe. Comparative Political Studies, 36(4): 432-466.

Goodwin, Matthew, J. (2014). 'A breakthrough moment or false dawn? The great recession and the radical right in Europe', in Clara Sanderlind (ed.) European Populism and Winning the Immigration Debate, European Liberal Forum. 
Goodwin, Matthew, J. (2015). 'The great recession and the rise of populist Euroscepticism in the United Kingdom'. Paper in Hans-Peter Kriesi and Takis Pappas (eds.) European Populism in the Shadow of the Great Recession, ECPR Press.

Goodwin, Matthew, J. and Caitlin Milazzo (2015). UKIP: Inside the Campaign to Redraw the Map of British Politics. Oxford University Press: Oxford.

Halikiopoulou, D., \& Vasilopoulou, S. (2014). Support for the far right in the 2014 European parliament elections: a comparative perspective. The Political Quarterly, 85(3): 285-288.

Halikiopoulou, D. and Vasilopoulou, S. (2013). "The Rise of the Golden Dawn". In: Giusto, H., Kitching, D. and Rizzo, S. (eds.) The Changing Faces of Populism: Systemic Challengers, in Europe and the U.S. Foundation for European Progressive Studies, Brussels: 107-124.

Hernández, E. and H. Kriesi. (2016). "The electoral consequences of the financial and economic crisis in Europe" European Journal of Political Research 55(2): 203-224. doi:10.1111/1475-6765.12122

Heywood, Andrew (2012). Political Ideologies: An Introduction. Palgrave Macmillan, 5th edition.

Hobolt, Sara, James Tilley and Susan Banducci. (2012). "Salience of responsibility: How government cohesion conditions performance voting." European Journal of Political Research. 52(2): 164-187.

Iversflaten, Elisabeth. (2005). "The Vulnerable Populist Right Parties: No Economic Realignment Fuelling Their Electoral Success," European Journal of Political Research, 44: 465-492.

Jackman, R. W., \& Volpert, K. (1996). Conditions favouring parties of the extreme right in Western Europe. British Journal of Political Science, 26(4: 501-521.

Kitschelt, Herbert. (1995). The Radical Right in Western Europe: A Comparative Analysis. Ann Arbor: University of Michigan Press.

Kriesi, Hanspeter, Pappas, Takis, S. (2015). European Populism in the Shadow of the Great Recession. European Consortium Political Research Press: Colchester.

Knigge, P. (1998). The ecological correlates of right-wing extremism in Western Europe. European Journal of Political Research, 34(2): 249-279.

Lewis-Beck, M. (1986). "Comparative Economic Voting." American Journal of Political Science 30: 315-346.

Lubbers, M., Gijsberts, M. \& Scheepers, P. (2002). "Populist radical right voting in Western Europe." European Journal of Political Research, 41(3): 345-378.

Lucassen, G., \& Lubbers, M. (2012). Who fears what? Explaining far-right-wing preference in Europe by distinguishing perceived cultural and economic ethnic threats. Comparative Political Studies, 45(5): 547-574.

Mair, P., \& Mudde, C. (1998). "The party family and its study." Annual Review of Political Science, 1(1): 211-229.

Meguid, Bonnie M. (2005). "Competition Between Unequals: The Role of Mainstream Party Strategy in Niche Party Success" American Political Science Review 3: 347-359. DOI: http://dx.doi.org/10.1017/S0003055405051701

Mudde, Cas, (2007). Populist Radical Right Parties in Europe. Cambridge University Press: Cambridge.

Mudde, Cas. (2014). "The Far Right and the European Elections." Current History 113.761: 98-103. Available at: http://works.bepress.com/cas_mudde/75

Mudde, Cas. (2016). "Far-Right Parties and the 2014 European elections: Consequences for the eurosceptic debate." in Nicholas Startin and Simon Usherwood (eds.) Handbook on Euroscepticism, Routledge. 
Norris, Pippa. (2005). Voters and Parties in the Electoral Market. Cambridge: Cambridge University Press.

Odmalm, Pontus and Tim Bale (2015). "Immigration into the mainstream: conflicting ideological streams, strategic reasoning and party competition." Acta Politica 50(4): 365378.

Pardos-Prado, Sergi (2015). "How Can Mainstream Parties Prevent Niche Party Success? Centre-Right Parties and the Immigration Issue." The Journal of Politics 77(2): 352-367.

Pardos-Prado, Sergi, Bram Lancee, and Inaki Sagarzazu (2014). "Immigration and electoral change in mainstream political space." Political Behavior 36(4): 847-875.

Rohrschneider, Robert and Stephen Whitefield. (2008). An Expert Survey of 208 parties in Europe.

Rohrschneider, Robert and Stephen Whitefield. (2012). The Strain of Representation. How Parties represent diverse Voters in Western and Eastern Europe. Oxford: Oxford University Press.

Rovny, Jan (2013). "Where do radical right parties stand? Position blurring in multidimensional competition.” European Political Science Review 5(1): 1-26.

Solt, Frederick. (2014). "The Standardized World Income Inequality Database." Working paper. SWIID Version 5.0, October 2014.

Spoon J-J and Klüver H. (2014). "Do parties respond? How electoral context influences party responsiveness." Electoral Studies 35: 48-60.

Stockemer, D. (2016). Structural data on immigration or immigration perceptions? What accounts for the electoral success of the radical right in Europe? Journal of Common Market Studies, 54(4): 999-1016.

Tavits, Margit and Natalia Letki. (2014). "From Values to Interests? The Evolution of Party Competition in New Democracies" The Journal of Politics 76 (1): 246-258.

Van der Brug, W., Fennema, M., \& Tillie, J. (2000). "Anti-immigrant parties in Europe: Ideological or protest vote? European Journal of Political Research." 37(1): 77-102.

Van der Brug, Wouter, Meindert Fennema, and Jean Tillie (2005). "Why Some Anti-Immigrant Parties Fail and Others Succeed. A Two-Step Model of Aggregate Electoral Support." Comparative Political Studies 38 (5): 537-753.

Van Heerden, S., de Lange, S. L., van der Brug, W., \& Fennema, M. (2013). 'The immigration and integration debate in the Netherlands: Discursive and programmatic reactions to the rise of anti-immigration parties." Journal of Ethnic and Migration Studies, 40(1): 119-136.

Van Spanje, J. (2010). "Contagious parties: Anti-immigration parties and their impact on other parties' immigration stances in contemporary Western Europe.” Party Politics, 16(5): 563586.

Werts, H., Scheepers, P., \& Lubbers, M. (2012). "Euro-scepticism and radical right-wing voting in Europe, 2002-2008: Social cleavages, socio-political attitudes and contextual characteristics determining voting for the radical right." European Union Politics, 14(2): 183-205.

Whitefield, Stephen and Robert Rohrschneider. (2015). "The Salience of European Integration to Party Competition: Western and Eastern Europe Compared." East European Politics and Societies and Cultures, 29(1): 12-39.

Whitefield, S., M. A. Vachudova, M. Steenbergen, R. Rohrschneider, G. Marks, M. Loveless, and L. Hooghe. (2006). "Do Expert Surveys Produce Consistent Estimates of Party Stances on European Integration? Comparing Expert Surveys in the Difficult Case of Central and Eastern Europe" Electoral Studies 26(1):50-61. DOI: 10.1016/j.electstud.2006.04.006 


\section{TABLES AND FIGURES}

Table 1: Classifications of Political Parties: By Party Family ${ }^{14}$

\begin{tabular}{|c|c|c|}
\hline Country & Centre Right & Radical Right \\
\hline Austria & ÖVP & FPÖ BZÖ \\
\hline Belgium & CD\&V N-VA LDD MR VLD & FN VB \\
\hline Bulgaria & BPU CEDB DSB NMSS UDF & NUA \\
\hline Czech Republic & KDU-CSL ODS & \\
\hline Denmark & KF NA VENSTRE & $\mathrm{DF}$ \\
\hline Estonia & ER IRL RE & \\
\hline Finland & KD KESK KOK SFP & PS \\
\hline France & MO DEM MPF NC UMP & $\mathrm{FN}$ \\
\hline Germany & CDU CSU FDP & \\
\hline Greece & ND & LAOS \\
\hline Hungary & FIDESZ KDNP MDF & MIEP*15 \\
\hline Ireland & FF FG PD & \\
\hline Italy & FI/PdL UDC & AN LN \\
\hline Latvia & JL LPP TP & TB/LNNK \\
\hline Lithuania & TS-LK LCS LRLS & \\
\hline Poland & $\mathrm{PO}$ & PIS LPR \\
\hline Portugal & CDS-PP PSD & \\
\hline Romania & PLD PNG PNL PNTCD UDMR & PRM \\
\hline Slovakia & KDH MKP SDKU & SNS \\
\hline Slovenia & NS SDS SLS & SNS \\
\hline Spain & CIU EAJ -PNV CC PP & \\
\hline Sweden & C FP KD M & $\begin{array}{l}\text { SWEDISH } \\
\text { DEMOCRATS }\end{array}$ \\
\hline The Netherlands & CDA CU SGP VVD & PVV \\
\hline The United Kingdom & $\mathrm{CON}$ & \\
\hline Number of Parties (N) & 71 & 20 \\
\hline
\end{tabular}

\footnotetext{
${ }^{14}$ Detailed classifications of parties, alongside the full names can be found in Appendix B.

15 The Hungarian Justice and Life Party (MIEP) did not meet the voting threshold in the RohrschneiderWhitefield expert survey.
} 
Table 2: Centre Right and Radical Right Party Performance, Economic Crisis: Statistical Models

\begin{tabular}{|c|c|c|c|}
\hline & $\begin{array}{c}\text { (M1) } \\
\text { Centre Right Model }\end{array}$ & $\begin{array}{c}\text { (M2) } \\
\text { Radical Right } \\
\text { Model I }\end{array}$ & $\begin{array}{c}\text { (M3) } \\
\text { Radical Right } \\
\text { Model II } \\
\text { (Selected) }\end{array}$ \\
\hline Salience: Immigration & $\begin{array}{l}\mathbf{0 . 0 3 3}^{*} \\
(2.03)\end{array}$ & $\begin{array}{c}0.05 \\
(0.76)\end{array}$ & $\begin{array}{c}0.03 \\
(1.16)\end{array}$ \\
\hline Position: Anti-Immigration & $\begin{array}{c}-0.01 \\
(-0.99)\end{array}$ & $\begin{array}{l}-0.09 \\
(-1.07)\end{array}$ & $\begin{array}{l}-0.005 \\
(-1.22)\end{array}$ \\
\hline Incumbent & $\begin{array}{l}-0.11^{* * * *} \\
(-3.65)\end{array}$ & - & - \\
\hline Position: Welfare & $\begin{array}{c}-0.02 \\
(-0.98)\end{array}$ & $\begin{array}{l}-0.022 \\
(-0.98)\end{array}$ & - \\
\hline Salience: Welfare & $\begin{array}{l}-0.03 \\
(-1.46)\end{array}$ & $\begin{array}{l}-0.004 \\
(-0.80)\end{array}$ & - \\
\hline Position: Market Economy & $\begin{array}{l}0.0002 \\
(-0.02)\end{array}$ & $\begin{array}{l}-0.005 \\
(0.23)\end{array}$ & - \\
\hline Salience: Market Economy & $\begin{array}{c}0.03 \\
(1.20)\end{array}$ & $\begin{array}{l}-0.002 \\
(-0.11)\end{array}$ & - \\
\hline Position: EU Opposition & $\begin{array}{l}0.004 \\
(0.17)\end{array}$ & $\begin{array}{l}-0.05 \\
(-1.85)\end{array}$ & $\begin{array}{l}-0.03 * \\
(-2.11)\end{array}$ \\
\hline Disproportionality Index & $\begin{array}{l}-0.007 \\
(-0.89)\end{array}$ & $\begin{array}{l}-0.02 \\
(-1.84)\end{array}$ & - \\
\hline Post-Communist Dummy & $\begin{array}{l}0.019 \\
(0.57)\end{array}$ & $\begin{array}{l}-0.02 \\
(-0.22)\end{array}$ & $\begin{array}{l}-0.02 \\
(-0.49)\end{array}$ \\
\hline $\begin{array}{l}\text { Change in Unemployment } \\
(2008-12)\end{array}$ & $\begin{array}{l}-0.002 \\
(-0.44)\end{array}$ & $\begin{array}{l}0.006 \\
(0.80)\end{array}$ & $\begin{array}{c}0.06 \\
(0.94)\end{array}$ \\
\hline $\begin{array}{l}\text { Change in GDP Growth } \\
(2008-12)\end{array}$ & $\begin{array}{c}-0.0009 \\
(-0.12)\end{array}$ & $\begin{array}{c}-0.01 \\
(-2.56)^{*}\end{array}$ & $\begin{array}{l}0.0007 \\
(-0.48)\end{array}$ \\
\hline $\begin{array}{l}\text { Change in Gini Index } \\
(2008-12)\end{array}$ & $\begin{array}{l}-0.35 \\
(-0.21) \\
\end{array}$ & $\begin{array}{l}-0.01 \\
(-1.01) \\
\end{array}$ & - \\
\hline Constant & $\begin{array}{l}0.06 \\
(0.46)\end{array}$ & $\begin{array}{c}0.63 \\
(1.78)\end{array}$ & $\begin{array}{c}0.20 \\
(1.11)\end{array}$ \\
\hline $\begin{array}{l}\mathrm{N} \\
\mathrm{R} 2\end{array}$ & $\begin{array}{c}70 \\
0.36\end{array}$ & $\begin{array}{c}19 \\
0.78\end{array}$ & $\begin{array}{c}19 \\
0.52\end{array}$ \\
\hline
\end{tabular}

Notes: OLS Regression Models run with robust standard errors. $t$ statistics in parentheses ${ }^{*} p$ $<0.05,{ }^{* * *} p<0.01,{ }^{* * *} p<0.001$ 
Table 3: Case Study Overall Key Patterns: Context of the Economic Crisis

\begin{tabular}{|c|c|c|c|c|}
\hline $\begin{array}{l}\text { Country } \\
\text { Context } \\
\text { (Western } \\
\text { Europe) }\end{array}$ & $\begin{array}{l}\text { Electoral } \\
\text { Volatility: } \\
\text { Centre Right } \\
\text { Incumbency } \\
- \\
\text { Punishment } \\
\text { Effect }\end{array}$ & $\begin{array}{l}\text { 'Incumbent } \\
\text { Parties' } \\
\text { Centre Right } \\
\text { 'Incumbent' } \\
\text { Parties } \\
\text { compete with } \\
\text { the Far Right } \\
\text { on } \\
\text { Immigration } \\
\text { (Emphasise } \\
\text { Immigration) }\end{array}$ & $\begin{array}{l}\text { 'Challenger' } \\
\text { Parties } \\
\text { Centre Right } \\
\text { 'Challenger' } \\
\text { Parties } \\
\text { compete with } \\
\text { the Far } \\
\text { Right on } \\
\text { Immigration } \\
\text { (Emphasise } \\
\text { Immigration } \\
\text { ) }\end{array}$ & $\begin{array}{l}\text { Electoral } \\
\text { Outcomes } \\
\text { ('Winners') }\end{array}$ \\
\hline $\begin{array}{l}\text { Belgium } \\
(2007- \\
2010)\end{array}$ & Yes & No & Yes & $\begin{array}{l}\text { Centre Right } \\
\text { 'Challengers' } \\
\text { (N-VA) }\end{array}$ \\
\hline $\begin{array}{l}\text { Netherlands } \\
(2006- \\
2010)\end{array}$ & Yes & No & Yes & $\begin{array}{l}\text { Centre Right } \\
\text { (VVD) and Far } \\
\text { Right } \\
\text { 'Challengers' } \\
\text { (PVV) }\end{array}$ \\
\hline $\begin{array}{l}\text { Denmark } \\
(2007- \\
2011)\end{array}$ & No & Yes & Yes & $\begin{array}{l}\text { Centre Right** } \\
\text { 'Incumbents' } \\
\text { (VENSTRE) }\end{array}$ \\
\hline $\begin{array}{l}\text { Finland } \\
(2007- \\
2011)\end{array}$ & Yes & No & $\mathrm{No}^{*}$ & $\begin{array}{l}\text { Far Right * } \\
\text { 'Challengers' } \\
\text { (PS) }\end{array}$ \\
\hline $\begin{array}{l}\text { France } \\
(2007- \\
2012)\end{array}$ & Yes & Yes & No* & $\begin{array}{l}\text { Far Right * } \\
\text { 'Challengers' } \\
(\mathrm{FN})\end{array}$ \\
\hline $\begin{array}{l}\text { Austria } \\
(2006- \\
2008)\end{array}$ & Yes & Yes & $\mathrm{No}^{*}$ & $\begin{array}{l}\text { Far Right * } \\
\text { 'Challengers' } \\
\text { (FPÖ and BZÖ) }\end{array}$ \\
\hline
\end{tabular}

Notes: ${ }^{*}=$ denotes 'relative' levels of electoral success (i.e. increase in vote share, but not entering government). ${ }^{* *}=$ denotes that although the centre right 'incumbent' party Venstre won the most votes and seats in Denmark, a centre left coalition was formed after the election, meaning that the centre right party now became the main opposition party. 
Table 4: Key Cases Breakdown (By \% Vote Share Change and Emphasis on Immigration)

\begin{tabular}{|c|c|c|c|}
\hline $\begin{array}{l}\text { Country \& Election } \\
\text { Years }\end{array}$ & Centre Right Party & $\begin{array}{l}\text { Radical Right } \\
\text { Party }\end{array}$ & $\begin{array}{l}\text { Electoral Outcomes } \\
\text { ('Winners') }\end{array}$ \\
\hline $\begin{array}{l}\text { Belgium } \\
(2007-2010)\end{array}$ & $\begin{array}{l}\text { N-VA } \\
(+8 \%) \\
\mathbf{5 . 0}\end{array}$ & $\begin{array}{l}\text { VB } \\
(-4 \%) \\
\mathbf{7 . 0}\end{array}$ & $\begin{array}{l}\text { Centre Right } \\
\text { 'Challengers' } \\
(\mathrm{N}-\mathrm{VA})\end{array}$ \\
\hline $\begin{array}{l}\text { Netherlands } \\
(2006-2010)\end{array}$ & $\begin{array}{l}\text { VVD } \\
(+6 \%) \\
5.2\end{array}$ & $\begin{array}{l}\text { PVV } \\
(+10 \%) \\
7.0\end{array}$ & $\begin{array}{l}\text { Centre Right (VVD) } \\
\text { and Far Right } \\
\text { 'Challengers' } \\
\text { (PVV) }\end{array}$ \\
\hline $\begin{array}{l}\text { Denmark } \\
(2007-2011)\end{array}$ & $\begin{array}{l}\text { NA } \\
(+2 \%) \\
\mathbf{5 . 6} \\
\text { VENSTRE } \\
(+1 \%) \\
\mathbf{5 . 1}\end{array}$ & $\begin{array}{l}\mathrm{DF} \\
(-3 \%) \\
\mathbf{6 . 6}\end{array}$ & $\begin{array}{l}\text { Centre Right } \\
\text { 'Incumbents' } \\
\text { (VENSTRE) }\end{array}$ \\
\hline $\begin{array}{l}\text { Finland } \\
(2007-2011)\end{array}$ & $\begin{array}{l}\text { KESK } \\
(-7 \%) \\
\mathbf{3 . 7} \\
\text { KOK } \\
(-2 \%) \\
\mathbf{3 . 8}\end{array}$ & $\begin{array}{l}\text { PS } \\
(+15 \%) \\
6.3\end{array}$ & $\begin{array}{l}\text { Far Right } \\
\text { 'Challengers' } \\
\text { (PS) }\end{array}$ \\
\hline $\begin{array}{l}\text { France } \\
(2007-2012)\end{array}$ & $\begin{array}{l}\text { UMP } \\
(-8 \%) \\
\mathbf{5 . 3}\end{array}$ & $\begin{array}{l}\text { FN } \\
(+4 \%) \\
6.9\end{array}$ & $\begin{array}{l}\text { Far Right } \\
\text { 'Challengers' } \\
(\mathrm{FN})\end{array}$ \\
\hline $\begin{array}{l}\text { Austria } \\
(2006-2008)\end{array}$ & $\begin{array}{l}\text { ÖVP } \\
(-8 \%) \\
\mathbf{5 . 3}\end{array}$ & $\begin{array}{l}\text { FPÖ } \\
(+7 \%) \\
\mathbf{7 . 0} \\
\text { BZÖ } \\
(+7 \%) \\
6.6\end{array}$ & $\begin{array}{l}\text { Far Right } \\
\text { 'Challengers' } \\
\text { (FPÖ and BZÖ) }\end{array}$ \\
\hline
\end{tabular}

Notes: \% Change in Vote Shares are outlined for both Centre Right and Radical Right Parties in parentheses. Bold figures denote Emphasis on Immigration (1-4= 'Low' Salience on Immigration, 5-7= 'High' Salience on Immigration) 
Figure 1: Regression Coefficient Plot with 95\% Confidence Intervals (Inclusion of Control Variables)

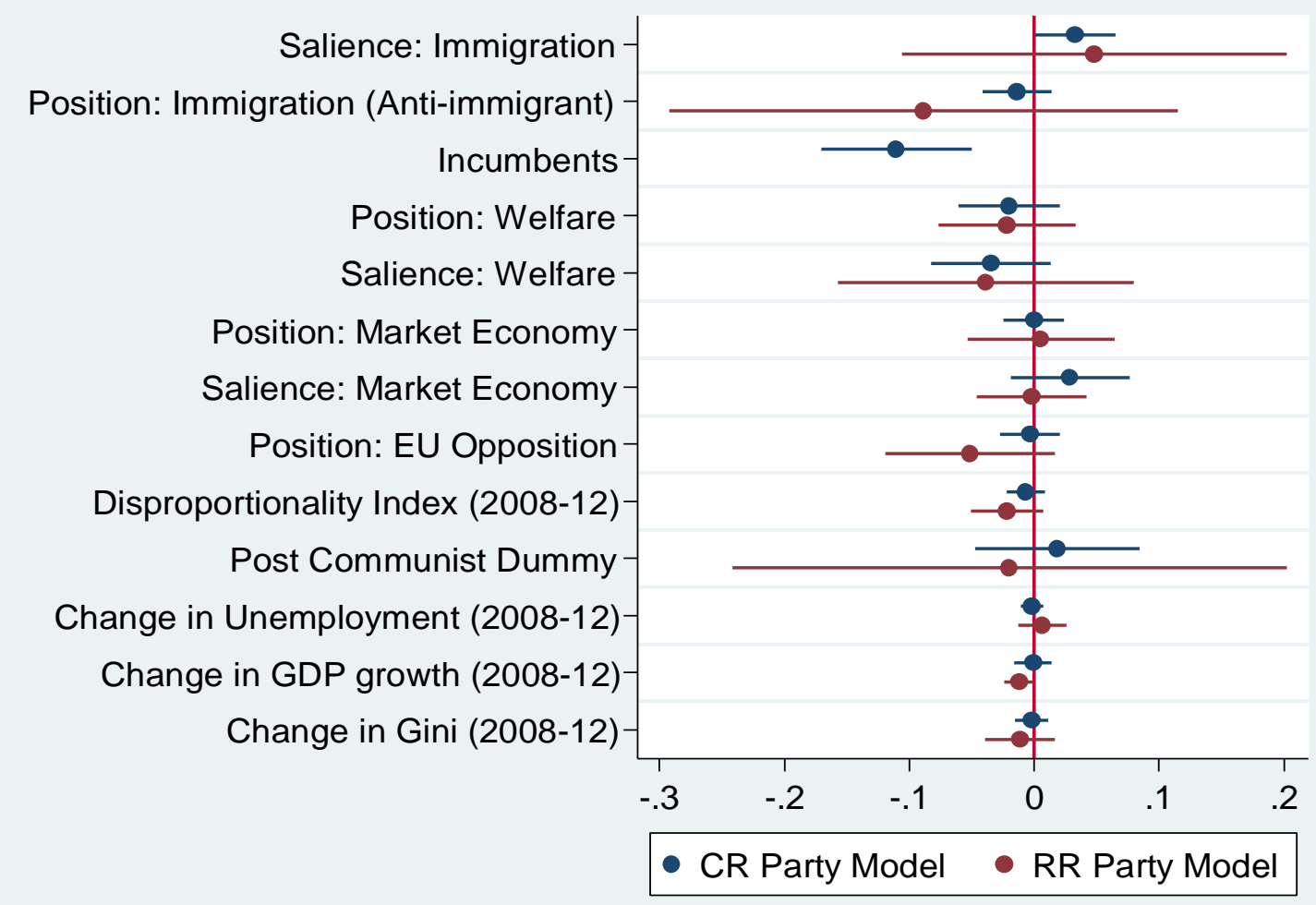


Figure 2: Graphical illustration of 'Strategic Emphasis'

Belgium (Flanders): Situation I: CR Party Electoral Success

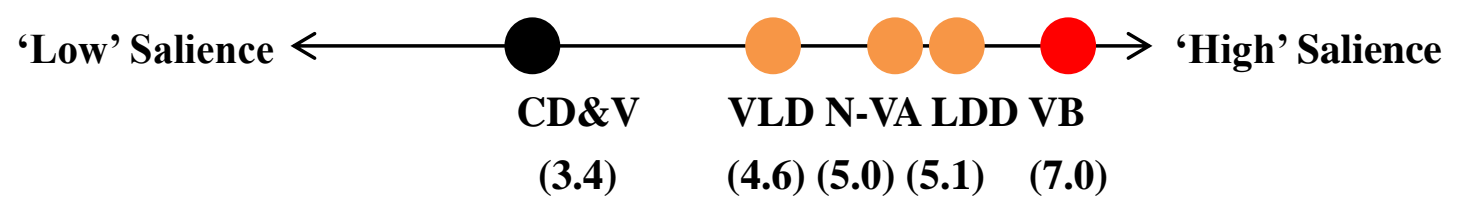

The Netherlands: Situation II: PRR and CR Party Electoral Success

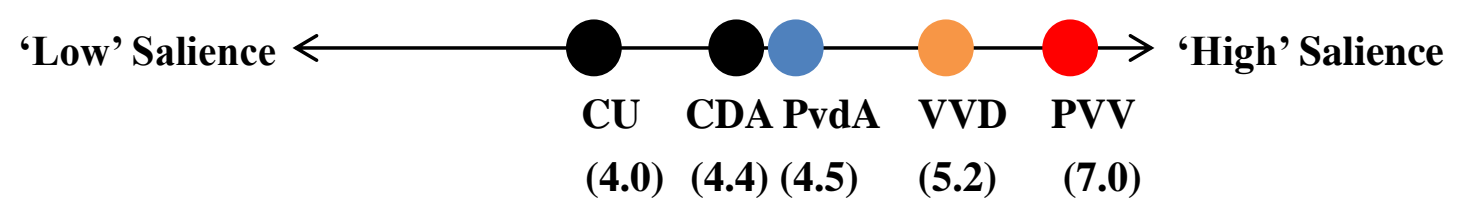

Finland: $\quad$ Situation III(i): PRR Party Electoral Success

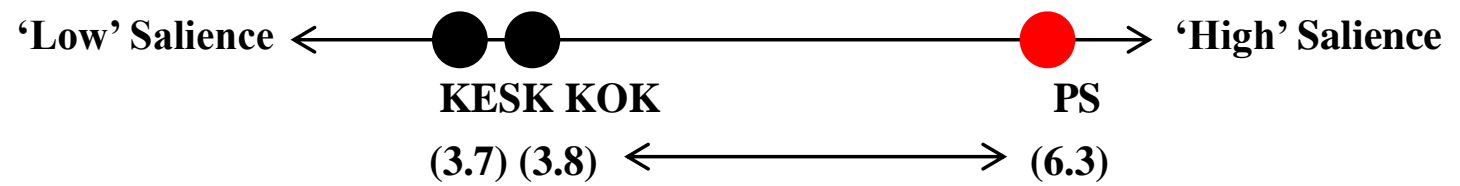

France: $\quad$ Situation III(ii): Anti-Incumbency Effects

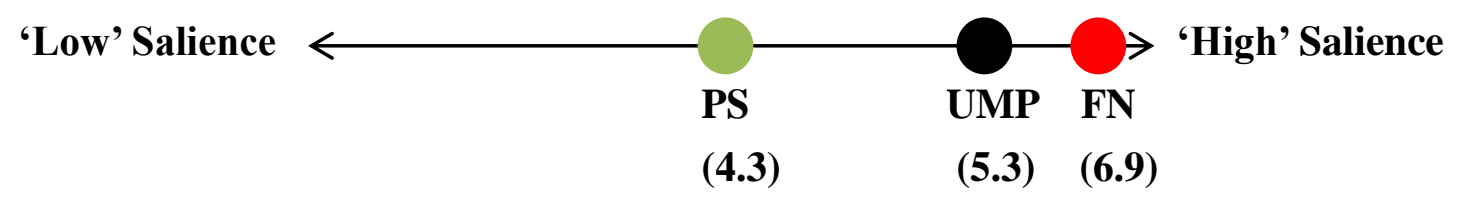

Notes: Emphasis placed on Immigration $(1-7)$ is denoted in parentheses. $1-4=$ 'Low' Salience on Immigration, 5-7= 'High' Salience on Immigration. Black: 'Incumbent' Centre Right Party. Orange: 'Challenger' Centre Right Party. Blue: 'Incumbent' Centre Left Party Red: 'Challenger' Radical Right Party. Green: 'Challenger' Centre Left Party. Source: Change in Party Performance Dataset 
Figure 3: Centre Right Electoral Performance and the Salience of Immigration of Incumbents and 'Challengers' Across West and East Europe

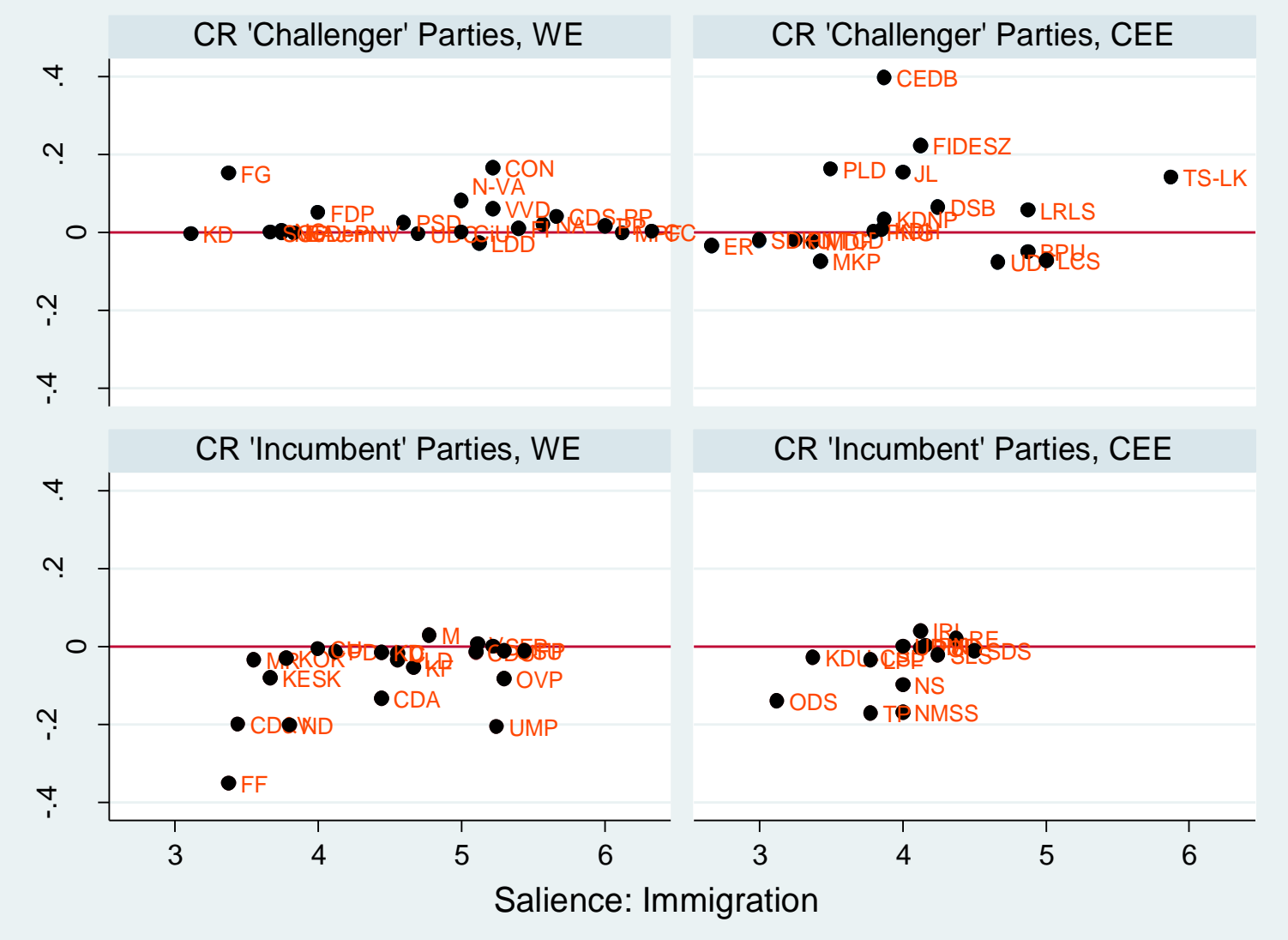

